\title{
FDI, Institutional Change, Employment and Services Growth in Megalopolises
}

\author{
Di Shang, Liyan Liu* \\ School of Economics and Management, Beijing Institute of Petrochemical Technology, Beijing, China \\ Email: *lucyliuliyan@bipt.edu.cn
}

How to cite this paper: Shang, D. and Liu, L.Y. (2019) FDI, Institutional Change, Employment and Services Growth in Megalopolises. Journal of Service Science and Management, 12, 682-696.

https://doi.org/10.4236/jssm.2019.125047

Received: June 24, 2019

Accepted: August 23, 2019

Published: August 26, 2019

Copyright $\odot 2019$ by author(s) and Scientific Research Publishing Inc. This work is licensed under the Creative Commons Attribution International License (CC BY 4.0).

http://creativecommons.org/licenses/by/4.0/

\begin{abstract}
This study was set out to identify the linkages between FDI, institutional change, employment and services growth in megalopolises in China. We choose the four super cities in China, Beijing, Shanghai, Guangzhou and Shenzhen, take government interference and openness as the proxy variable of institutional change, based on Douglas production function and using data from Year 2006 to 2017, we investigated the relations between FDI, institutional change, employment, and services growth with fixed effect panel data model. Findings show that FDI presented a significant positive impact on the service economic growth of the four megalopolises, while the number of employees in the service industry has a negative effect on the growth of the service industry, which is contrary to the common sense; With respect to institutional change, openness presented a strong positive effect and effect of government intervention is not significant; the city's fixed investment and R \& D investment of service sectors also presented an unclear effect.
\end{abstract}

\section{Keywords}

FDI, Institutional Change, Employment, Economic Growth in Services

\section{Introduction}

Since the reform and opening policy, Chinese economic system has been changed in responding to the initiative of "opening up". Contributing to the more open economic environment, China's economy is increasingly prosperous with a good economic environment, more job creation and rapid economic development.

Foreign direct investment (FDI) has different degrees of influence on the host state's economy, employment, efficiency, etc. A lot of scholars argue that foreign direct investment has the impact of positive spillover on the host country's GDP, ${ }^{*}$ Corresponding author. 
but this point should be analyzed based on the state condition. Some developing countries can't completely absorb the technologies brought by FDI due to the average education level of human resources, thus having experienced the negative spillover effect of FDI. FDI has job creation effects and wage effects on the host country labor market.

Since the output of China's services sector exceeds the half of yearly GDP, China has entered the model of service economics. The development of service economics based on the service industry has become the core driver of economic development of super large cities. Workers in the service industry accounted for more than 50\% in four large cities as Beijing, Shanghai, Guangzhou and Shenzhen. These four cities featured various resources endowments and developing modes of big cities in China and are all well-opened economy with comparatively matured industry structure and rapid growth of service sectors. With regard to Beijing, the center of China's economics and politics, its employers in the service industry occupied $80.6 \%$, and GDP of its service sector is up to $80.5 \%$ of GDP of the city, which indicated that its service industry made a big contribution to the economic growth. In addition, Beijing, as one of the first batch of cities implementing the opening of service sector, did an exemplary job in the development of the service industry, becoming the sample that other cities followed.

Many factors in the society influence the GDP growth of the service industry, including institutional changes, FDI, employment scale of the service industry and income of on-the-job staff in the service industry. The author attempted to research the interactive effect between the above factors and the economy of services sector in this paper to solve the bottleneck in the economic development of the service industry. In this paper, we selected four large cities-Beijing, Shanghai, Guangzhou and Shenzhen, as the research objects. For these four cities, their workers in the service industry accounted for 58.4\% in average from 2006 and 2017; GDP of the service industry was $63.6 \%$ of total GDP averagely; foreign funds utilized by the service industry increased rapidly from 2.27 billion USD of 2006 to 11.26 billion USD of $2017^{1}$. Their governmental budgetary expenditures and average wages of staff in the service industry showed the trend of slow rise, and total trade import and output show the upward tendency. Under the condition of China's economy is developing well, although GDP of the service industry of four cities showed the trend of growth year by year, the growth rate showed the opposite trend. Therefore, how to resolve this issue through institutional change and the utilization of foreign direct investment is the key to solving the GDP growth bottleneck of the service industry and promoting the development of the service industry.

As the four biggest super cities in China with different natural endowment and economic resources and unique growth path, Beijing, Shanghai, Shenzhen ${ }^{1}$ Data are calculated from the original data from Beijing Statistical Year Book (2018), Shanghai Statistical Year Book (2018), Shenzhen Statistical Year Book (2018), and Guangzhou Statistical Year Book (2018). 
and Guangzhou are featured for most of the fast growing of big cities in developing countries. We selected these four cities to investigate the relations between FDI, institutional change, employment and services growth. Literature in this retrospect is quite few, and the impact of FDI together with institutional change of these four opening super-cities on their services growth has unique indications for the service sectors development of most big cities in developing countries who are expecting to upgrade their industrial structure and growth their service economies. Owing to the data obtainability, we have not found the effective proxy variable for the quality of employment, especially the exact number of high-tech and high-degree employees in each sector of the four city's service sector, hence could not effectively measure the exact impact of employment quality on services growth, which is a limitation for our research. The rest of the paper is organized as 2) Literature Review; 3) Model Setting and Data Discrimination; 4) Empirical Results and discussion, with pooled regression, fixed effect regression and further tests of the results; 5) Conclusion.

\section{Literature Review}

Scholars made different conclusions about FDI and national industrial structure. Wang Xinhua (2007) used the model of fixed effects to make the analysis of short-term and long-term effects based on the data of the service sector from 1997 to 2003, and proposed that FDI has the negative effect on the changes of industrial structure in the short run, but it has the positive spillover effect in the long run [1]. Guo Kesha (2000) thought that foreign direct investment had significant influences on the structure of three industries of China and the internal structure of each industry, including positive influences and negative influences [2]. Zhao (2013) discussed the influence of FDI on the industrial structure from the scale and structure, and his/her studies indicate that the country should establish a better investment environment to attract more FDI into the service industry, thus bringing the positive effect of FDI spillover, and achieving the upgrading of national industrial structure [3]. Liu (2012) [4] studied FDI's employment structure effects based on China's data from 1985-2008, and found that FDI would limit and even have negative impetus on China's employment, while in the short-term FDI inflow would promote employment in manufacturing and service sector, especially service sector in the long run, hence improve the employment structure.

FDI and institutional change affect the economic growth of a region and a country to a certain extent. Pravin (2012) used the panel data of 10 years to analyze the factors of influencing FDI to BRICS. He believed that trade opening degree and market scale coefficient have a positive influence on FDI [5]. Zheng Xianyong (2010) claimed that to make FDI play the role of promoting economic growth, we must value the relations of the unity of opposites between institutional stability and institutional changes, and maintain the unity, continuity and coordination of foreign investment policies reforming [6]. Kenj (2017) re- 
searched the benefit effect of the liberalization of the trade and FDI, and made the conclusion that if the marginal cost difference between export and FDI industries is small enough, and the liberalization of FDI brings more benefits, then the liberalization of trade is beneficial. Based on the above research results, the author further indicated that the synchronized liberalization of trade and foreign direct investment brought benefits definitely [7]. Soo (2013) took Malaysia as an example, researched the relation between import and export trade and FDI through the Gravity model, and pointed out FDI conforms to the observational model of complementary relationships between FDI and trade [8]. Tang Qianning (2016) took Chongqing city as an example, proved that FDI in the services sector had a subtle effect on promoting institutional change in the region in the short run, but it had a big influence on the improvement of institutional quality of a region [9]. Wang Xia (2007) argued that as a part of China's policy of reform and opening up, FDI' effect on Chinese institutional change will be inevitably subject to the influence of the overall process of China's reform and opening up and other institutional reform, and drew a conclusion that FDI promotes Chinese institutional change [10]. Elena (2019) investigated the impact of foreign direct investment in developed and developing countries on economic growth under different macro-mechanisms, and the research results showed that systems affect the strategies, structure and competition of multinational corporations significantly, thus influencing economic growth [11].

FDI, as the driving force of promoting economic growth of the service industry, promotes the increase of national economics. Chew (2010) analyzed the relation between FDI and economic growth of Japan through the Bivariate and multivariate Granger causality test and got that FDI has the long-term positive one-way causality on GDP [12]. Panagiotis (2015) used the panel data to analyze the relations between foreign direct investment and economic growth, and the empirical study indicated that there exist long-term positive cointegration relations between FDI stock and economic growth [13]. Argiro (2011) analyzed the data of the European Union and ASEAN from 1970 to 2003 through panel data analysis method, and made the conclusion that the increase in per capita GDP of ASEAN countries promotes the growth of FDI, for example, Singapore in the ASEAN, obtaining more FDI due to its growth in GDP. While there is a two-way causality relation in Thailand, he pointed out that the relation between FDI and economic growth should be analyzed based on the condition of each country [14]. Liu (2011) [15] used VAR and ECM model studied the long-run and short-term effects of FDI on China's economic growth and employment structure, and found that FDI tends to decrease economic growth in the long run, and FDI inflows do crowd out domestic capitals, and reduce employment growth. Yao (2012) constructed a dynamic model of endogenous variables in a system including FDI in the service sector, value added in the service sector, GDP, which affected and depended on each other, and drew a conclusion that there was no two-way causality relation between FDI and GDP [16]. Dierk (2008), 
conducted the cointegration test for foreign direct investment of 28 countries, and argued that FDI had no one-way positive influence on economic growth of a country [17].

The above studies analyzed the influence of FDI, foreign trade and institutional change on economic growth of each country and the national industrial structure, but few studies are focusing on the service industry in promoting the economic growth of China. Considering the difference in the status quo of each country, the author selected representative cities such as Beijing, Shanghai, Shenzhen and Guangzhou as the samples to conduct the research on the relations between institutional change, FDI, wage level, employment and services growth.

\section{Model Setting and Data Description}

1) Theoretical Analysis

After entering the 21st century, countries in the world start to explore new economic development modes. They made a great effort to change traditional economic development pattern under which more labor, capital and resources were invested to promote economic development, and took the innovation as the new engine for economic growth. In the 1930s, mathematician Cobb and economist Douglas put forward the Cobb-Douglas production function (hereinafter referred to as C-D function), which renders a feasible solution to the evaluation of contribution to material resources and human resources.

C-D production function model:

$$
Y=A K^{\alpha} L^{\beta}
$$

In the formula, $Y$ means gross domestic product; $K$ stands for capital investment; $L$ means labor investment; $A$ indicates the total factor productivity (comprehensive technical level). $\alpha$ and $\beta$ respectively stand for capital elasticity and labor elasticity.

When $\alpha+\beta=1$, that is, the production scale remains unchanged, we took the natural logarithm of both sides of (1), and derive the linear equation as follows:

$$
\ln Y=\ln A+\alpha \ln K+\beta \ln L+\mu
$$

From the production function model, it can be found that main factors of determining the development of the service sector are capital investment in the service industry, labor investment and comprehensive technical level. Through the Cobb-Douglas production function, we can understand the contributions of capital investment, labor investment and technical level to the service sector. In this paper, the researcher adopts C-D production function to analyze 4 large service-driven cities, the influence of FDI, employment, institutional change and other factors on services growth and the interactive effects between them.

To investigate the influence of institutional changes, FDI, employment in the service sector and other factors on services growth, the researcher should make the analysis of effects caused by these factors. Institutional change involves economic systems, legal systems, administrative systems, etc., which can be dis- 
cussed to enhance understanding of institutional changes ${ }^{2}$. Considering the research background of this paper and economic development practices, the researcher explored the institutional change mainly based on the specific practices of "reform" and "opening up", especially economic development. Therefore, while studying the influence of institutional change on urban services growth, the researcher took government interference and openness as the proxy variable of institutional change.

Reducing government interference can change the subject and mechanism of resources allocation, break through the economic monopoly of state-owned enterprises, release advanced productive forces, promote the improvement of resources allocation efficiency and upgrading of industrial structure, and promote the concentration of economic resources in the services sector. Therefore, taking government interference as the proxy variable is suitable. Owing to the opening up, each industry in the economy can be involved in international division of labor, and is able to achieve more advanced technologies, management experience and abundant resource each industry optimizes the allocation of resources to concentrate on more advanced industries and sectors, thus to promote economic development. Therefore, it is proper to use the indexes showing the openness level as the proxy variable of economic system changes.

2) Econometric Model Setting and Data Description

In addition to institutional changes and foreign direct investment may affect the growth of the service industry, the technical level, fixed assets investment in the service industry and employment in the service industry are also important factors affecting technological progress or factor input. Considering a variety of factors, the following Econometric model is set in this paper:

$$
\begin{aligned}
\ln S G D P= & \beta_{0}+\beta_{1} \ln S F D I_{i t}+\beta_{2} \ln S E M P_{i t}+\beta_{4} \ln S F I X_{i t}+\beta_{7} \ln R D_{i t} \\
& +\beta_{5} O P E N_{i t}+\beta_{6} G O V_{i t}+\epsilon_{i t}
\end{aligned}
$$

where subscript $i$ represents the city and t represents the year; $S G D P_{i t}$ is the growth in output of the service industry, that is, the economic growth of the service industry to be studied in this paper; $S F D I_{i t}$ refers to the FDI actually used in the service sector; $S E M P_{i t}$ shows the number of labor input in service industry, which is the number of year-end employment in each city; $F I X_{i t}$ is the city's fixed ${ }^{2}$ Economic system changes promoted changes of the system of property rights, stimulated the initiative of workers, reduced transaction costs, promoted social division of labor, and achieved economic growth. In the aspect of legal systems, legal systems were perfected (Ruling the country by law was emphasized in the modification of the Constitution in 1999; The modification of the Constitution in 2004 focuses on protecting human rights and private property rights, etc.), and characteristics of market economy were taken into consideration while legal systems were established. Legal systems effectively provide a guarantee for the sound development of Chinese economy. Proxy variables may be the number of legal practitioners, the number of legal institutes. In terms of administrative systems, institutions were subject to reform in 2003, 2008 and 2014. On one hand, the relations between the government and markets were clarified through streamlining administration and delegating more powers to lower-level governments and society; on the other hand, the functions of social management and public service departments were enhanced and improved. This not only reduces administration costs, improves the administration efficiency, but also injects more vitality to the development of market economy. Hence, investment in science, education, culture and health, investment in infrastructures, etc. can be selected as the proxy variable. 
capital investment, expressed in fixed-asset investment of the city; $\ln R D_{i t}$ is a technical level, expressed by annual R \& D input of the city. The following variables are used as proxy variables of institutional change factors: in terms of openness, $O P E N_{i t}$ refers to the degree of dependence on foreign trade, which is expressed by the ratio of the city's annual total import and export volume to the city's GDP. GOV $V_{i t}$ is an indicator of government intervention, measured by the ratio of annual city government spending to annual city GDP.

The growth index of the service industry is directly based on the service industry GDP of the four cities from 2006 to 2017.

Taking 2006 as the base year, the GDP of the service sector, the amount of FDI utilized in the service sector, and the average wage of service workers were all de-inflated based on 2006, and exchange rate was converted at the average exchange rate of current year.

After de-inflation and exchange rate conversion, the original data is logarithmically processed according to Equation (3) and shows the following characteristics: According to the following mean value, standard deviation, maximum and minimum value of the overall data in Table 1, the dataset is balanced panel data with small standard deviations and no outliers.

Table 1. Statistical summary of data.

\begin{tabular}{|c|c|c|c|c|c|c|}
\hline Variable & & Mean & Std. Dev. & Min & Max & Observations \\
\hline \multirow[t]{3}{*}{ Lnsgdp } & Overall & 9.571195 & 0.4334131 & 8.686203 & 10.31396 & $\mathrm{~N}=48$ \\
\hline & Between & & 0.3958323 & 8.927854 & 10.1259 & $\mathrm{n}=12$ \\
\hline & Within & & 0.202891 & 9.307525 & 9.923024 & $\mathrm{~T}=4$ \\
\hline \multirow[t]{3}{*}{ Lnsfdi } & Overall & 5.122674 & 1.56419 & 2.17776 & 7.340753 & $\mathrm{~N}=48$ \\
\hline & Between & & 0.4053247 & 4.53752 & 5.863887 & $\mathrm{n}=12$ \\
\hline & Within & & 1.514229 & 2.53379 & 6.693936 & $\mathrm{~T}=4$ \\
\hline \multirow[t]{3}{*}{ Lnsemp } & Overall & 6.280127 & 0.3815914 & 5.61287 & 6.912942 & $\mathrm{~N}=48$ \\
\hline & Between & & 0.1927189 & 5.98237 & 6.553755 & $\mathrm{n}=12$ \\
\hline & Within & & 0.3329296 & 5.903771 & 6.749806 & $\mathrm{~T}=4$ \\
\hline \multirow[t]{3}{*}{ Lnfix } & Overall & 8.263671 & 0.52416 & 7.149657 & 9.083323 & $\mathrm{~N}=48$ \\
\hline & Between & & 0.3450589 & 7.746042 & 8.789071 & $\mathrm{n}=12$ \\
\hline & Within & & 0.4040767 & 7.610259 & 8.82575 & $\mathrm{~T}=4$ \\
\hline \multirow[t]{3}{*}{ Lnrd } & Overall & 5.978323 & 0.9446575 & 3.100835 & 7.349086 & $\mathrm{~N}=48$ \\
\hline & Between & & 0.5674318 & 4.883246 & 6.705248 & $\mathrm{n}=12$ \\
\hline & Within & & 0.7687332 & 4.195912 & 7.165786 & $\mathrm{~T}=4$ \\
\hline \multirow[t]{3}{*}{ Open } & Overall & 0.8706303 & 0.4831128 & 0.1841462 & 1.699 & $\mathrm{~N}=48$ \\
\hline & Between & & 0.1823652 & 0.5955627 & 1.1118 & $\mathrm{n}=12$ \\
\hline & Within & & 0.4497373 & 0.1597748 & 1.478987 & $\mathrm{~T}=4$ \\
\hline \multirow[t]{3}{*}{ Gov } & Overall & 0.2061633 & 0.0580058 & 0.0965134 & 0.3005327 & $\mathrm{~N}=48$ \\
\hline & Between & & 0.0258557 & 0.1746869 & 0.2482806 & $\mathrm{n}=12$ \\
\hline & Within & & 0.0523338 & 0.1175482 & 0.308473 & $\mathrm{~T}=4$ \\
\hline
\end{tabular}




\section{Empirical Results and Discussion}

\section{1) Pooled Regression}

As a frame of reference, pooled regression was carried out first. Here, it is assumed that the regression equation of Beijing, Shanghai, Shenzhen, and Guangzhou are the same and individual specific effects are absent, that is, the pooled regression equation of the four cities is uniformly set as follows:

$$
y_{i t}=\alpha+x^{\prime} \beta+z_{i}^{\prime} \delta+\epsilon_{i t}
$$

where $x_{i t}$ does not include a constant term.

Cluster robust standard error pooled regression, robust standard error pooled regression and standard error pooled regression were performed respectively. The results were as follows in Table 2.

It can be seen from the results in Table 2 that the three error forms are obviously different. The pooled regression results of the robust standard error and the standard error are close, except gov which is not significant. The results of cluster-robust standard error regression are quite different from the other two. In the cluster-robust standard error pooled regression, only the open results were significant on the $10 \%$ level, and the other variables were not significant. Although the four cities are all large open cities with developed service industries and have service economy development models driven by service industry growth, each city has its own economic endowments and resources allocation among various sectors, there may be its own characteristics that are time-invariant, that is, individual differences or heterogeneity. It is assumed that the four cities have the same regression equation in pooled regression, which may be not true in the real world. Therefore, we need to further confirm the validity of pooled regression by $\mathrm{F}$ test in Table 3.

Since the $\mathrm{P}$ value of $\mathrm{F}$ test in the last row of Table 3 is 0.0000 , the null hypothesis is strongly rejected. Therefore, there are individual differences and pooled regression results are not valid. Four cities should be allowed to have their own intercept items.

Table 2. Comparison of three pooled regression.

\begin{tabular}{|c|c|c|c|c|c|c|c|c|c|}
\hline \multirow{2}{*}{ Lnsgdp } & \multicolumn{3}{|c|}{ Cluster-Robust Standard Error } & \multicolumn{3}{|c|}{ Robust Standard Error } & \multicolumn{3}{|c|}{ Standard Error } \\
\hline & Coef. & Std. Err. & $P>|t|$ & Coef. & Std. Err. & $P>|t|$ & Coef. & Std. Err. & $P>|t|$ \\
\hline Lnsfdi & 0.1314138 & 0.0828173 & 0.211 & 0.1314138 & 0.0456876 & 0.006 & 0.1314138 & 0.0476141 & 0.009 \\
\hline Lnsemp & -07204522 & 0.6641512 & -0.357 & -0.7204522 & 0.3487617 & 0.045 & -0.7204522 & 0.2638341 & 0.009 \\
\hline Lnfix & 0.5177384 & 0.2286282 & 0.108 & 0.5177384 & 0.1161504 & 0.000 & 0.5177384 & 0.1427097 & 0.001 \\
\hline Lnrd & 0.3767584 & 0.2383658 & 0.212 & 0.3767584 & 0.1200797 & 0.003 & 0.3767584 & 0.0958745 & 0.000 \\
\hline Open & -0.3353916 & 0.1184339 & -0.066 & -0.3353916 & 0.0893211 & 0.001 & -0.3353916 & 0.0957525 & 0.001 \\
\hline Gov & 0.3322742 & 1.323217 & 0.818 & 0.3322742 & 0.7980951 & 0.679 & 0.3322742 & 0.950502 & 0.728 \\
\hline _Cons & 7.115233 & 3.04469 & 0.102 & 7.115233 & 1.381692 & 0.000 & 7.115233 & 1.223647 & 0.000 \\
\hline
\end{tabular}


Table 3. F-test.

\begin{tabular}{|c|c|c|c|c|}
\hline Lnsgdp & Coef. & Std. Err. & $\mathrm{T}$ & $P>|t|$ \\
\hline Lnsfdi & 0.0795094 & 0.025388 & 3.13 & 0.002 \\
\hline Lnsemp & -0.497874 & 0.1486245 & -3.35 & 0.002 \\
\hline Lnfix & 0.1812361 & 0.0813795 & 2.23 & 0.034 \\
\hline Lnrd & 0.1047716 & 0.0622692 & 1.68 & 0.103 \\
\hline Open & 0.2807603 & 0.081341 & 3.45 & 0.002 \\
\hline Gov & -1.18655 & 0.5385779 & -2.20 & 0.035 \\
\hline _Cons & 10.16676 & 0.714548 & 14.23 & 0.000 \\
\hline Sigma_u & 0.41517735 & & & \\
\hline Sigma_e & 0.06042366 & & & \\
\hline Rho & \multicolumn{4}{|c|}{0.97925832 (fraction of variance due to $\mathrm{u} \_\mathrm{i}$ ) } \\
\hline \multicolumn{5}{|c|}{$\mathrm{F}$ test that all $\mathrm{u} \_\mathrm{i}=0: \mathrm{F}(11,30)=12.53$ Prob $>\mathrm{F}=0.0000$} \\
\hline
\end{tabular}

However, since the F test does not use the cluster robust standard error, and the standard error is only about half of the cluster standard error, the F test here is not fully effective and LSDV (Least Square Dummy Variable Test) Test is needed to further determine the validity and scienticness of the results.

The results in Table 4 indicate that all dummies of the three cities are significant on the $10 \%$ level; therefore, we can reject the null hypothesis that all dummies are 0 value. That is, there are individual specific effects, and each city has its time-invariant heterogeneity. We should use Fixed Effects Model (FE) to conduct fixed effect regression ${ }^{3}$ rather than simple pooled regression.

2) Fixed Effect Regression and Random Effect Regression

Given individual specific effects as $i$, we can get

$$
y_{i t}=x_{i t}^{\prime} \beta+z_{i}^{\prime} \delta+\mu_{i}+\bar{\varepsilon}_{i}
$$

Take the average of the time over both sides of the Equation (5), we will get

$$
\bar{y}_{i}=\bar{x}_{i}^{\prime} \beta+z_{i}^{\prime} \delta+u_{i}+\bar{\varepsilon}_{i}
$$

Minus Equation (4) we can get the form of mean-differencing ${ }^{4}$ :

$$
\begin{gathered}
y_{i t}-\bar{y}_{i}=\left(x_{i t}-\bar{x}_{i}\right)^{\prime} \beta+\left(\varepsilon_{i t}-\bar{\varepsilon}_{i}\right) \\
\tilde{y}_{i t} \equiv y_{i t}-\bar{y}_{i}, \quad \tilde{x}_{i t} \equiv x_{i t}-\bar{x}_{i}, \quad \tilde{\varepsilon}_{i t} \equiv \varepsilon_{i t}-\bar{\varepsilon}_{i}
\end{gathered}
$$

Then,

$$
\bar{y}_{i t}=\bar{x}_{i t}^{\prime} \beta+\bar{\varepsilon}_{i t}
$$

Since there is no " $u_{i}$ " here, and assume $\tilde{\varepsilon}_{i t}$ and $\tilde{x}_{i t}$ are irrelevant, then we can use OLS to estimate $\hat{\beta}_{F E}$, and here $\beta$ is the fixed effects estimator, or ${ }^{3}$ The word "fixed effects" may be misunderstood. Even in fixed effects model, individual-specific effects $-u_{i}$ is still a random one, but not a fixed constant.

${ }^{4}$ This transformation is usually called "mean-differencing" or "time demeaning". 
within estimator here.

Therefore, we use individual-specific effects regression to investigate the topic. Since individual-specific effects model involve fixed effects model and random effects model, we perform the two respectively. Fixed effect model regression is as follows in Table 5.

And the results of random effects model regression are presented in Table 6.

From the results of fixed effects model and random effects model, we can see that the coefficients in random effects model are on average larger than fixed effects model, besides, city's fixed investment, R \& D investment of services sectors and government interference in fixed effects model are insignificant, while in random effect model, and only government interference is insignificant. Results are strongly differentiated in the two regressions. In order to further investigate the validity and scientificity of the above two model estimation results, Hausman Test is carried out on the fixed effect model and random effect model respectively to determine the scientificity of the above results.

Test results in Table 7 show that $\mathrm{P}$ value equals 0.0000 , which strongly reject the Ho, that is the difference in coefficients is systematic, and fixed effects regression is effective.

Table 4. Least square dummy variable test.

\begin{tabular}{ccccc}
\hline City & Coef. & Std. Err. & $\mathrm{t}$ & $\mathrm{P}>|\mathrm{t}|$ \\
\hline 2 & 0.3191153 & 0.0635936 & 5.02 & 0.010 \\
3 & 0.9818472 & 0.1302026 & 7.54 & 0.005 \\
4 & 0.7344856 & 0.1026962 & 7.15 & 0.006 \\
_Cons & 0.8620718 & 1.706587 & 0.51 & 0.648 \\
\hline
\end{tabular}

Table 5. Fixed effect model regression.

\begin{tabular}{|c|c|c|c|c|c|c|}
\hline Lnsgdp & Coef. & Std. Err. & $\mathrm{t}$ & $P>|t|$ & [95\% Conf. & Interval] \\
\hline Lnsfdi & 0.0795094 & 0.0199144 & 3.99 & 0.002 & 0.0356782 & 0.1233406 \\
\hline Lnsemp & -0.497874 & 0.1116111 & -4.46 & 0.001 & -0.7435283 & -0.2522197 \\
\hline Lnfix & 0.1812361 & 0.1047038 & 1.73 & 0.111 & -0.0492153 & 0.4116875 \\
\hline Lnrd & 0.1047716 & 0.0822984 & 1.27 & 0.229 & -0.076366 & 0.2859093 \\
\hline Open & 0.2807603 & 0.0705785 & 3.98 & 0.002 & 0.1254181 & 0.4361026 \\
\hline Gov & -1.18655 & 0.7284507 & -1.63 & 0.132 & -2.789859 & 0.4167596 \\
\hline _Cons & 10.16676 & 0.5711553 & 17.8 & 0.000 & 8.909653 & 11.42386 \\
\hline Sigma_u & 0.41517735 & & & & & \\
\hline Sigma_e & 0.06042366 & & & & & \\
\hline Rho & \multicolumn{6}{|c|}{0.97925832 (fraction of variance due to $\mathrm{u} \_\mathrm{i}$ ) } \\
\hline
\end{tabular}


Table 6. Random effect model regression.

\begin{tabular}{ccccccc}
\hline Lnsgdp & Coef. & Std. Err. & $\mathrm{z}$ & $\mathrm{P}>|\mathrm{t}|$ & [95\% Conf. & Interval] \\
\hline Lnsfdi & 0.1314138 & 0.0383468 & 3.43 & 0.001 & 0.0562554 & 0.2065721 \\
Lnsemp & -0.7204522 & 0.2309154 & -3.12 & 0.002 & -1.173038 & -0.2678664 \\
Lnfix & 0.5177384 & 0.1132756 & 4.57 & 0.000 & 0.2957222 & 0.7397546 \\
Lnrd & 0.3767584 & 0.088505 & 4.26 & 0.000 & 0.2032917 & 0.550225 \\
Open & -0.3353916 & 0.0712427 & -4.71 & 0.000 & -0.4750247 & -0.1957586 \\
Gov & 0.3322742 & 0.7697701 & 0.43 & 0.666 & -1.176448 & 1.840996 \\
_Cons & 7.115233 & 1.117659 & 6.37 & 0.000 & 4.924662 & 9.305803 \\
Sigma_u & 0.41517735 & & & & & \\
Sigma_e & 0.06042366 & & & & & \\
Rho & & 0.0 (fraction of variance due to u_i) &
\end{tabular}

Table 7. Hausman test (fixed effects and random effects).

\begin{tabular}{|c|c|c|c|c|}
\hline & \multicolumn{4}{|c|}{ Coefficients } \\
\hline & (b) & (B) & (b-B) & Sqrt (Diag(V_b-V_B $)$ ) \\
\hline & $\mathrm{FE}$ & $\mathrm{RE}$ & Difference & S.E. \\
\hline Lnsfdi & 0.0795094 & 0.1314138 & -0.0519043 & 0.0192891 \\
\hline Lnsemp & -0.497874 & -0.7204522 & 0.2225782 & 0.1443551 \\
\hline Lnfix & 0.1812361 & 0.5177384 & -0.3365023 & 0.0821646 \\
\hline Lnrd & 0.1047716 & 0.3767584 & -0.2719867 & 0.0817602 \\
\hline Open & 0.2807603 & -0.3353916 & 0.616152 & 0.1338764 \\
\hline Gov & -1.18655 & 0.3322742 & -1.518824 & 0.5331543 \\
\hline _Cons & 10.16676 & 7.115233 & 3.051524 & 0.770265 \\
\hline & $\mathrm{b}=$ consi & ander Ho and & btained from & \\
\hline & $\mathrm{B}=$ inconsisten & r Ha, efficien & r Ho; obtaine & om xtreg \\
\hline & $\begin{array}{l}\text { Test: } \mathrm{H} \\
\text { chi2 }(6\end{array}$ & $\begin{array}{l}\text { erence in coe } \\
-B)^{\prime}\left[\left(V_{-} b-V_{-}\right.\right.\end{array}$ & $\begin{array}{l}\text { its not system } \\
1)](b-B)=33\end{array}$ & \\
\hline & & Prob $>$ chi 2 & 00 & \\
\hline
\end{tabular}

\section{Discussion}

From the fixed regression results, the coefficient of service industry FDI is 0.089 , and is significant on the level of $1 \%$, which indicates that every 1 percent increase in foreign investment will lead to a 0.089 percent increase in the output value in the service industry. This positive correlation shows that the inflow of FDI in the service industry will drive the growth of service economy of four cities.

The coefficient of year-end employment in the service industry is significantly negative, which is -0.492 and is significant on the $1 \%$ level, indicating that the growth in employment in the four cities service industries will reduce the growth of service industry output. Contrary to common sense, where increased labor 
input usually increases rather than reduces output. The four super-large cities of Beijing, Shanghai, Shenzhen and Guangzhou have already developed economic development models driven by service industry. In recent years, they have been committed to developing high-end service industries featured by knowledgeand technology-intensiveness. The development of high-end service industry and information technology will increase the demand for high-end service talents, such as high-tech R \& D personnel, high-end financial talents, management talents with international service management experience, and reduce employee number in general service industry, such as catering, accommodation, logistics sectors, and so on. With the development and the increasing scale of high-end service sector, the service industry will recruit less people labor-intensive employees. Therefore, when the high-end service industry in four cities develops at a high speed, the output value of the service industry increases, and the service industry further transforms and upgrades, which is reflected in the decrease in the number of labor-intensive employees in the general service industry, whose decrease will result in the decrease of total employee number in the service industry. Furthermore, the four cities are currently undergoing transformation and upgrading of the service industry, focusing on the development of high-end service industries with knowledge- and technology-intensiveness, and controlling the expansion of labor-intensive service sectors.

From the regression results, the fixed investment and $\mathrm{R} \& \mathrm{D}$ investment in the service industry of the four cities do not play a significant role in the growth of the service industry. The return rate of the fixed assets investment and R \& D investment of the service industry in the current four cities needs to be improved.

With respect to institutional change, regression results show that the coefficients of openness in service industry and service trade are significantly positive, indicating that the open environment and free service trade have significant positive effects on the service industry growth and service economy development of the four cities. The negative effects of government intervention are not significant, indicating that from the current development of service industries in Beijing, Shanghai, Shenzhen and Guangzhou, the four cities are committed to building a better external environment to encourage and promote the development of the service industry.

\section{Conclusions}

In this paper, we chose the city-level panel data of Beijing, Shanghai, Shenzhen and Guangzhou in China from 2006 to 2017. By building a fixed effect panel data model in world economy context, with government interference and openness as the proxy variable of institutional change, we investigated the impact of institutional change, FDI, employment and technology level on the growth of service economy and service industry in megacities.

The results show that the inflow of FDI in the service industry has a significant positive impact on the growth of the service industry in the four megacities 
within the time interval of this study, that is, the foreign direct investment in the service industry has a significant positive spillover effect. The increase in the number of employed people in the service industry has a significant inhibition effect on the growth of the output value of the service industry. That is, the increase in the number of employees cannot significantly promote the growth of the output value of the service industries in the four largest cities. In terms of institutional change, the openness of service industry and service trade will significantly promote the growth of service industry, while the impact of government intervention on the development of service economy is not significant. Similarly, city's fixed capital investment and R \& D investment in service industries have no significant impact on the growth of service industries in the four cities.

It is worth noting that the number of employees in the service industry has a negative effect on the growth of the service industry in four cities, which is contrary to the conclusions obtained from the analysis of most production function growth factors. This shows that the increase of employment in the service industry will lead to the output growth of service industry, indicating that the four super-large cities of Beijing, Shanghai, Shenzhen and Guangzhou have entered the stage of development of knowledge- and technology-intensive high-end service industries. The requirements for the service industry practitioners have been transformed from purely labor-intensive, which is dominated by "quantity", to knowledge and technology-intensive, which is dominated by "quality". The excessive investment of workers in the labor-intensive general service industry cannot achieve the growth of the service industry in the four megacities in the current development period.

Beijing, Shanghai, Shenzhen and Guangzhou are in the transition period of high-speed and high-end development of the service industry. The pilot service industry in Beijing is fully open, and foreign direct investment in service industry has entered a new stage of development. In order to better promote the knowledge spillover effect of foreign direct investment (SFDI) in the service industry,

China is in the transition period of industrial structure upgrading, confronted with the task of developing strategic emerging industries and transforming traditional industries. Foreign direct investment has entered a new stage of development. In promoting the high-end and innovative development of the service industries of the four megacities, we should pay attention to the following aspects: First, we should reasonably choose the sectors FDI flowed in. We should let FDI with advanced management experience and new business mode to be invested into high-end service sectors and emerging industries to further improve the knowledge spillover effect of foreign investment; second, to focus on the cultivation of high-end talents in the service industry. The growth of the service industry in megacities depends on high-end knowledge-intensive service industry employees. High-end service talents can be cultivated through various ways of scientific research and scientific and technological cooperation or can be introduced through various channels. Third, improve the return rate of $\mathrm{R} \& \mathrm{D}$ 
investment in service industry. We should focus R \& D on high-end services and innovative development and pay attention to the protection of intellectual property rights of service industry $\mathrm{R} \& \mathrm{D}$ investment, to increase the willingness to invest in service research and development; Fourth, further opening of service industry. Based on the full opening of Beijing service industry, Shanghai, Shenzhen, and Guangzhou will gradually realize the all-round opening of the service industry, to promote the high-end and innovative development of the service industry in megacities.

\section{Supporting Projects}

1) The Coupling Mechanism between FDI and Employment Structure in Beijing, Beijing Municipal Education Commission Project (SM201510017001). 2) The Optimization of Beijing's Industrial Structure Based on SFDI, Beijing Social Science Foundation Project (13JGC072). 3) The Optimization of Beijing's Industrial Structure Based on FDI in Services, Beijing URT Project (2019J00140). 4) Support Project of High-level Teachers in Beijing Municipal Universities in the Period of 13th Five-year Plan.

\section{Conflicts of Interest}

The authors declare no conflicts of interest regarding the publication of this paper.

\section{References}

[1] Wang, X. (2007) The Effect of FDI in Services on Economic Growth in China: An Empirical Analysis Based on Panel Data of Nine Industries. Journal of International Trade, No. 9, 70-73.

[2] Guo, K. (2000) Research on the Impact of Foreign Direct Investment on China's Industrial Structure. Management World, No. 2, 34-45+63.

[3] Zhao, Q. and Niu, M. (2013) Influence Analysis of FDI on China's Industrial Structure Optimization. Procedia Computer Science, 17, 1015-1022. https://doi.org/10.1016/j.procs.2013.05.129

[4] Liu, L. (2012) FDI and Employment by Industry: A Co-Integration Study. Modern Economy, 3, 16-22. https://doi.org/10.4236/me.2012.31003

[5] Pravin, J. (2012) Determinants of Foreign Direct Investment in BRICS Economies: Analysis of Economic, Institutional and Political Factor. Procedia-Social and Behavioral Sciences, 37, 5-14. https://doi.org/10.1016/j.sbspro.2012.03.270

[6] Zheng, X. and Hu, C. (2010) Evaluation of China's Foreign Direct Investment Policy from the Perspective of Institutional Stability and Change. Special Zone Econo$m y$, No. 8, 240-241.

[7] Fujiwara, K. (2017) Trade and FDI Liberalization in a General Oligopolistic Equilibrium. Japan and the World Economy, 41, 45-49. https://doi.org/10.1016/j.japwor.2016.12.003

[8] Goh, S.K., Wong, K.N. and Tham, S.Y. (2013) Trade Linkages of Inward and Outward FDI: Evidence from Malaysia. Economic Modelling, 35, 224-230. https://doi.org/10.1016/j.econmod.2013.06.035 
[9] Tang, Q. (2016) Discussion on the Relationship between Service Industry FDI and Institutional Change-Taking Chongqing City as an Example. Journal of Commercial Economics, 15, 194-197.

[10] Wang, X. and Chen, L. (2007) The Influence of FDI on China's Institutional Change and Its Empirical Analysis. Nanjing Journal of Social Sciences, 11, 7-17.

[11] Ketteni, E. and Kottaridi, C. (2019) The Impact of Regulations on the FDI-Growth Nexus within the Institution-Based View: A Nonlinear Specification with Varying Coefficients. International Business Review, 28, 415-427. https://doi.org/10.1016/j.ibusrev.2018.11.001

[12] Lee, C.G. (2010) Outward Foreign Direct Investment and Economic Growth: Evidence from Japan. Global Economic Review, 39, 317-326.

https://doi.org/10.1080/1226508X.2010.513143

[13] Pegkas, P. (2015) The Impact of FDI on Economic Growth in Eurozone Countries. The Journal of Economic Asymmetries, 12, 124-132. https://doi.org/10.1016/j.jeca.2015.05.001

[14] Moudatsou, A. and Kyrkilis, D. (2014) FDI and Economic Growth: Causality for the EU and ASEAN. Journal of Economic Integration, 26, 554-577.

https://doi.org/10.11130/jei.2011.26.3.554

[15] Liu, L. (2011) FDI and Economic Development: Evidence from Mainland China. Journal of Service Science and Management, 4, 419-427. https://doi.org/10.4236/jssm.2011.44047

[16] Yao, Z. (2012) Foreign Direct Investment and Economic Growth in Service Industry-An Empirical Study Based on China. Finance Trade Economics, No. 6, 89-96.

[17] Herzer, D., Klasen, S. and Nowak-Lehmann, F. (2008) In Search of FDI-Led Growth in Developing Countries: The Way Forward. Economic Modelling, 25, 793-810. https://doi.org/10.1016/j.econmod.2007.11.005 